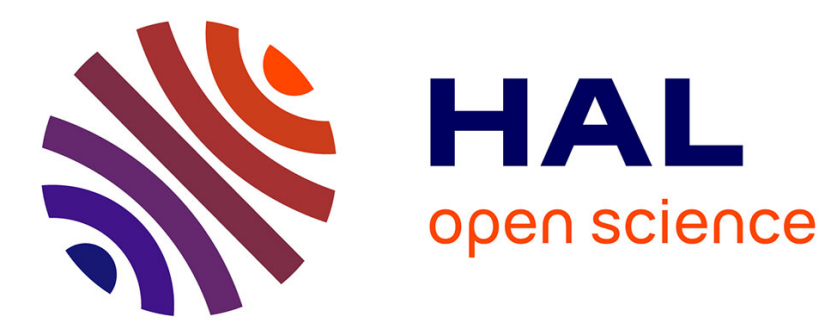

\title{
The use of accounting and stock market data to predict bank financial distress: the case of East Asian banks
}

\author{
Isabelle Distinguin, Amine Tarazi, Jocelyn Trinidad
}

\section{To cite this version:}

Isabelle Distinguin, Amine Tarazi, Jocelyn Trinidad. The use of accounting and stock market data to predict bank financial distress: the case of East Asian banks. 2008. hal-00785449v2

HAL Id: hal-00785449

https://hal-unilim.archives-ouvertes.fr/hal-00785449v2

Preprint submitted on 13 Dec 2013

HAL is a multi-disciplinary open access archive for the deposit and dissemination of scientific research documents, whether they are published or not. The documents may come from teaching and research institutions in France or abroad, or from public or private research centers.
L'archive ouverte pluridisciplinaire HAL, est destinée au dépôt et à la diffusion de documents scientifiques de niveau recherche, publiés ou non, émanant des établissements d'enseignement et de recherche français ou étrangers, des laboratoires publics ou privés. 


\title{
THE USE OF ACCOUNTING AND STOCK MARKET DATA TO PREDICT BANK FINANCIAL DISTRESS: THE CASE OF EAST ASIAN BANKS
}

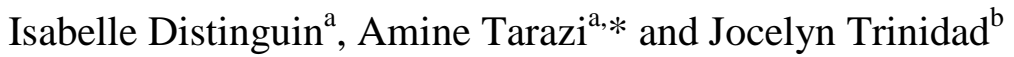

\begin{abstract}
This paper investigates whether market information could add to accounting information in the prediction of bank financial distress in Asia. A stepwise logit model is first estimated to isolate the optimal set of accounting indicators and then extended to include market indicators. Dummy variables are also introduced in the model to account for the possible existence of balance sheet structure effects. Our results show that market indicators bring in additional information in the prediction process and this contribution holds whatever the importance of the ratio of market funded liabilities over total assets. We also find that market indicators are significant to predict banks' financial distress whatever assets structure. However, for non traditional banks, that is for banks with a low ratio of net loans to total assets, market information seems difficult to interpret.
\end{abstract}

JEL classification: G21, G28

Keywords: Bank, Bank Failure, Bank Risk, East Asia

\footnotetext{
${ }^{a}$ Université de Limoges, LAPE, 5, rue Félix Eboué, 87031 Limoges, France

${ }^{\mathrm{b}}$ University of the Philippines, College of Business Administration, Diliman, Quezon City, Philippines

*Corresponding author: Telefax: +33-555-436934; E-mail address: amine.tarazi@ unilim.fr

This paper was prepared for the European Commission ASIA-LINK project B7-3010/2005/105-139: Safety and Soundness of the Financial System. The contents of this paper are the sole responsibility of the authors and can under no circumstances be regarded as reflecting the position of the European Commission.
} 


\section{Introduction}

Given the major role played by banks as intermediaries in the financial system, it is essential that supervisors assess banks' financial health on a frequent basis. To predict banks' financial situation, early warning systems (EWS) have been designed but most models mainly focus on accounting data which are backward looking. Moreover, the reliability of accounting data has always been questioned given the very persistent issues of information quality and diversity in the application of accounting principles. ${ }^{1}$ As a result, users of financial information also look into other available information that could aid them in making more informed decisions. Market data are considered as a viable complement to accounting information in the conduct of assessing bank financial health. Thus, the use of market data is more and more considered to enhance the supervisory process (Berger, Davies, and Flannery [2000], Flannery [1998]).

Several studies have been conducted to determine if market information can complete accounting information to predict banks' financial health. In the US case, Curry, Elmer, and Fissel [2007] and Evanoff and Wall [2001] show that the use of market indicators improves the assessment of banks financial health. It is also the case in Europe. Indeed, Gropp, Vesala and Vulpes [2006] and Distinguin, Rous and Tarazi [2006] show that market indicators add to the predictive power of accounting indicators and that they can predict deteriorations in banks' financial condition at relatively long horizons.

With the occurrence of the Asian Crisis, there was heightened interest in the role of the banking sector in Asian economies especially since most studies in this area pinpoint particular weaknesses in the sector which aggravated the crisis. However, in the Asian case, little has been written on the prediction of banks' financial degradations since most studies focus on early-warning models of banking crises (Demirgüc-Kunt and Degatriache, [2000]).

The objective of this paper is to determine if, in the Asian banking sector, equity market information can complete accounting information to predict banks' financial distress. The paper also looks into the reliability and stability of market indicators given the presence of balance sheet structure effects. Indeed, it may be more difficult for market participants to

\footnotetext{
${ }^{1}$ Users of financial information are on the alert with respect to the quality of accounting information since management (the company) has the incentive to "select" generally accepted accounting principles that could favorably present financial performance. On the other hand, the development and adoption of International Accounting Standards (IAS) aim to eliminate diversity and country differences in the application of accounting principles.
} 
assess the financial health of banks heavily involved in loan activities as they are supposed to be more opaque (Diamond, 1984). By contrast, banks heavily relying on market funding may be more accurately scrutinized by the market. Using eight Asian countries as a point of study, this paper also aims to further investigate potential differences between banks from the tiger economies and banks from emerging markets.

The paper is organized as follows: Section 2 presents the methodology adopted for our study. Section 3 describes the data and the set of early accounting and market indicators used in our estimations. Section 4 presents the results and section 5 concludes.

\section{Methodology}

The main purpose of this study is to determine if equity market indicators can bring in information not yet contained in accounting data to predict bank financial distress. In order to do this, a stepwise process is employed which initially solely considers the set of accounting indicators for the prediction model. The process is later on extended to include a large set of market indicators to determine the marginal contribution of these indicators in the prediction process. Then, to test the existence of balance sheet structure effects, dummy variables are introduced. Thus, we determine the effect of balance sheet structure on the effectiveness of the selected market indicators.

To begin with, we need to determine an event that could represent a change in the financial situation of a bank. Studies conducted in the US mainly use explicit bank failures or supervisory ratings downgrades as in Curry, Elmer and Fissel [2007], Kolari, and al. [2002] and Gunther, Levonian, and Moore [2001]. In the European case, sharp downgrades (Gropp, Vesala and Vulpes [2006]) are used as proxies for actual bank failure or downgrade announcements by private rating agencies ${ }^{2}$ (Distinguin, Rous and Tarazi [2006]) as proxies for financial distress. In Asia, there have been only few actual bank failures. Thus, in this paper, following Distinguin, Rous and Tarazi [2006], we consider downgrading announcements from the three major rating agencies Fitch, Moody's and Standard and Poor's to represent deteriorations in the bank's financial condition.

\footnotetext{
${ }^{2}$ Due to confidentiality laws in most countries, it is difficult to gain access to explicit supervisory ratings in Europe.
} 
Accounting $\mathrm{C}_{\mathrm{ji}}$ and market $\mathrm{M}_{\mathrm{li}}$ indicators are computed to estimate the probability of a downgrade. However, accounting and market data are not available at the same frequencies. As such, the starting point for this study is December $31^{\text {st }}$ of each year - when accounting information is available. Events taking place during the following calendar year are then considered, which avoids the interpolation of missing accounting data and ensures that the information content of accounting data is not inappropriately upward biased.

For each bank in the sample, the dependent variable $\mathrm{Y}$ is equal to:

- 1 , if the bank is downgraded by at least one rating agency with no upgrading taking place during the entire calendar year and no downgrade or upgrade during the last quarter of the preceding year;

- 0 , if the rating remains unaltered or if the bank experienced an upgrade during the calendar year; and;

- NA (not available), for all other cases.

Figure 1 illustrates the definition of the dependent variable $Y(0,1, N A)$.

\section{Insert Figure 1}

As in Distinguin, Rous and Tarazi [2006], the following logit model is employed to estimate the probability of a downgrade:

$$
\operatorname{Prob}\left\{Y_{i}=1\right\}=\Phi\left(\alpha+\sum_{j=1}^{J} \beta_{j} C_{j i}+\sum_{l=1}^{L} \gamma_{l} M_{l i}\right)
$$

where $\mathrm{C}_{\mathrm{ji}}$ and $\mathrm{M}_{\mathrm{li}}$ are the $\mathrm{j}^{\text {th }}$ accounting indicator and the $\mathrm{l}^{\text {th }}$ market indicator, respectively, and $\Phi($.$) denotes the cumulated logistic distribution function. Maximum likelihood estimators$ of the coefficients $\left(\alpha, \beta_{j}, \gamma_{l}\right)$ are used and robust Huber-White covariance matrix estimation allows for possible misspecification of the error term distribution.

In the selection of the optimal predictors of bank financial distress, only the predictive power of the accounting indicators is considered first. The best indicators are selected through a 
stepwise process. ${ }^{3}$ The procedure is then extended to include market indicators in order to determine their marginal contribution to the prediction model. Market indicators are added to the optimal subset of accounting indicators obtained in the first step.

However, due to the possible existence of balance sheet structure effects, there is a need to test for the stability of the contribution of market indicators in the prediction process. This is tested in the model through the inclusion of dummy variables. We also conduct estimations of the different models on restricted samples of banks.

\section{Sample and Indicators}

\subsection{Sample}

Our sample consists of 64 banks from Hong Kong, Korea, Taiwan, Singapore, Malaysia, Thailand, Indonesia and the Philippines. These banks are regularly listed in their home countries and are rated by at least one of the three rating agencies Fitch, Moody's and Standard and Poor's.

The banks are categorized into two groups A and B. The bank is classified as group A, if it is from Hong Kong, Korea, Taiwan or Singapore; then group B, if from Malaysia, Thailand, Indonesia or the Philippines. It is more prudent to group the banks into country categories as the two country groups exhibit different characteristics particularly with respect to the level of development of their financial system.

Table 1 presents the distribution of banks by country and specialization for the combined groups A and B, group A and group B. Information is taken from Bankscope Fitch IBCA.

\section{Insert Table 1}

Accounting data come from Bankscope Fitch IBCA and weekly market data are obtained from Datastream International. In order to avoid noise related to the 1997 financial crisis, we

\footnotetext{
${ }^{3}$ As a rule of thumb, a $10 \%$ level for type 1 error is retained and a Max (Min) LR statistic is used as a criterion for adding (ruling out) each potential indicator to (from) the selected set.
} 
restrict our sample to the post-crisis period 1999-2004. Table 2 shows some descriptive statistics on summary accounting information for combined and separate bank groups.

\section{Insert Table 2}

\subsection{Financial Deterioration Indicator}

The downgrades used in this study are announced by the rating agencies Fitch, Moody's and Standard and Poor's. This information is obtained from Bankscope Fitch IBCA and FinInfo. Table 3 gives details on the downgrades considered in this study. Since several restrictions are applied on the construction of the binary dependent variable $\mathrm{Y}$, only a limited number of "clean" downgrades are subsequently considered in this study. For example, if several downgrades occur during the calendar year, we consider them as a single event. Of the total forty-five (45) combined downgrades from the ratings agencies, only twenty (20) "clean" downgrades are used for the estimations.

\section{Insert Table 3}

\subsection{Accounting Indicators}

We use a set of accounting ratios (see Table 4) commonly used in the assessment of bank financial health. These ratios can be grouped into four categories corresponding to the CAEL rating categories: Capital, Asset quality, Earnings and Liquidity.

Following Distinguin, Rous and Tarazi [2006], we consider first order differences of these ratios as explanatory variables which seems preferable to the use of ratios in level as Curry, Elmer and Fissel [2007], Gunther, Levonian, and Moore [2001. Indeed, we aim to predict changes in the financial condition of the bank not its financial condition. More importantly, our study requires equal consideration of banks regardless of their initial financial strength. More precisely, the downgrade of a sound and safe bank as compared to a modestly performing bank can only be captured by a change in the values of the ratios of this bank. Consequently, $\mathrm{C}_{\mathrm{ji}}$ is defined as the annual change in the value of the accounting ratio $\mathrm{R}_{\mathrm{ji}}$. 
Insert Table 4

\subsection{Market Indicators}

We use weekly equity prices to compute the set of market indicators used in this study. These indicators and their expected relationship with the probability of bank failure are presented in Table 5 .

The effects of shocks or the presence of abnormal returns can be captured by the variables LOGP, RCUM, EXCRCUM, RCUM_NEG, EXCRCUM_NEG and CAR, while we use $\triangle B E T A$ and $\triangle D D$ to detect risk changes and changes in the probability of failure, respectively.

\section{Insert Table 5}

\section{Empirical Results}

First, we consider the predictive power of the sole accounting indicators via a stepwise process. Then, the process is extended to include market indicators. This enables to assess their marginal contribution to the prediction process. Dummy variables, to capture possible balance sheet structure effects, are also introduced in the model in order to test for the stability of the contribution of market indicators.

As a preliminary step, univariate regressions are conducted. Regional results pertain to combined groups A and B; while group A pertains to banks from Hong Kong, Singapore, Korea and Taiwan; and group B to banks from Malaysia, Indonesia, Thailand and the Philippines. For regional estimations, we take into account country group differences by introducing a dummy variable GRPB which is equal to one for banks belonging to group B. 


\subsection{Univariate Regression Results}

Table 6 shows the results for the univariate regressions on the accounting and market indicators for Asian banks. Results are only reported when the coefficients are at least significant at the $10 \%$ level.

Insert Table 6

Regional results show that changes in the profitability/earnings ratios NIR_EA and ROAA are significant at the $5 \%$ level. The negative sign of the coefficients is consistent with the expected negative relationship between profitability and bank financial distress. The changes in the liquidity ratios NL_DEP and NL_TEA are also significant at $1 \%$ and 5\%, respectively. But, the negative sign of the coefficients is not consistent with the expected negative relationship between liquidity and bank financial distress. For market indicators, EXCRCUM and $\triangle \mathrm{DD}$ are significant at the $5 \%$ level. The sign of the coefficient of EXCRCUM is the expected one but the sign of the coefficient associated to the change in the distance to default $\triangle \mathrm{DD}$ is opposite to the presumed one. ${ }^{4}$

For group A, three liquidity indicators, $\triangle$ LIQASS_TOTDB, $\triangle$ NL_TEA, and $\triangle \mathrm{NL} \_D E P$, are significant at the $5 \%, 10 \%$ and $1 \%$ levels respectively but with the wrong signs. Significant market indicators are CAR, EXCRCUM, LOGP, RCUM, RCUMNEG and $\triangle$ BETA. The signs of the coefficients of these indicators all conform to the expected relationship with bank financial distress, except for $\triangle \mathrm{BETA}$.

Group B results also prove to be interesting showing that the accounting indicators $\triangle \mathrm{KP} \_D E P S T F, \triangle \mathrm{KP} \_L I A B, \Delta \mathrm{NL} \_D E P$ and $\triangle \mathrm{ROAA}$ appear as significant. For these banks, capital ratios are also meaningful in the prediction process. The sign of the coefficients all conform to the expected relationship with bank financial distress except for $\triangle$ NL_DEP. LOGP, $\triangle \mathrm{DD}$ and $\triangle \mathrm{RISK} \_$TOT are the significant market indicators for group B. However,

\footnotetext{
${ }^{4}$ An explanation for this result may be that, in our sample of banks, the median of the annual change in total liabilities is \$ 179.84 million for downgraded banks and \$ 354.06 for banks with a stable rating or an upgrade. Thus, even if the market value of bank equity starts decreasing before the actual downgrade, it is possible that the relatively lower increase in the value of debt for downgraded banks is driving the distance to default in the opposite direction for these banks. Indeed, the strike price of the Call option used to calculate the distance to default is the value of debt. And, a lower strike price implies a lower default probability.
} 
only the sign of the coefficient of the variable $\Delta$ RISK_TOT is consistent with the expected relationship with bank financial distress.

Interestingly, $\Delta \mathrm{DD}$, which is the annual change of the distance to default, is a significant indicator for the regional and group B results but its coefficient has the wrong sign. $\Delta D_{\text {D_TRIM }}^{5}$ (the quarterly change of the distance to default) was also calculated, eventually emerging significant at $10 \%$ for group B with a coefficient that has the expected sign. In this case, the same variable computed on a different basis behaves inconsistently. The sign of the coefficient associated with $\triangle B E T A$ also exhibits the wrong relationship with bank financial distress. The behaviour of these two market indicators is noteworthy at this point. The variables seem to show a certain level of sensitivity with respect to the assumptions used in the computation particularly with the case of $\triangle \mathrm{DD}$. $\triangle \mathrm{BETA}$ is also a variable that can be computed on the basis of several measures.

\subsection{Contribution of Accounting Indicators}

After conducting the univariate regressions and initially determining the set of indicators that are significant, stepwise procedures are considered. Table 7 is a presentation of the results for the stepwise procedure based on the full set of accounting indicators.

\section{Insert Table 7}

For the combined groups A and B, the stepwise results show that earnings ratios are the optimal predictors of bank financial distress. $\triangle$ NIR_EA and $\triangle \mathrm{ROAE}$ are significant at the $5 \%$ and $10 \%$ levels, respectively. The sign of the coefficients also conform to the expected inverse relationship of profitability with bank financial distress. These results are consistent with the results of the univariate regressions conducted on the regional set of banks where earnings ratios emerge as significant. Also, the dummy variable GRPB, that takes the value of one for group B banks, is significant at 5\% showing that Group A and Group B banks behave differently.

\footnotetext{
${ }^{5} \Delta \mathrm{DD}$ TRIM is not retained in the study because interpolated accounting data is needed for the computation of this indicator which may bias the results.
} 
For group A banks, the stepwise procedure yields earnings ( $\triangle$ NIR_EA) and asset quality ( $\triangle$ LLR_TA) indicators as the best predictors of bank financial distress, while it was mostly liquidity ratios that emerged as significant in the initial regressions. The signs of the coefficients conform to the expected relationship with bank distress. Only one accounting indicator emerges after the stepwise procedure for group B banks: $\triangle$ NL_DEP at the 5\% significance level but with the wrong sign.

\subsection{Additional Contribution of Market Indicators}

To determine the set of market indicators that contribute further to the prediction of bank distress, the accounting information based model is extended to include market indicators. Table 8 shows the results of the stepwise procedure.

\section{Insert Table 8}

The market indicators that significantly add to the predictive power of the accounting indicators for the regional set are EXCRCUM and $\triangle \mathrm{DD}$ which is consistent with the initial univariate regression results. These indicators are significant at the 5\% and $1 \%$ level of significance, respectively. The sign of the coefficient of the indicator EXCRCUM conforms to the expected relationship with bank financial distress while $\Delta \mathrm{DD}$ does not.

For group A banks, the market indicators LOGP and $\triangle \mathrm{BETA}$ increase the predictive power of a model based solely on accounting indicators. These indicators are both significant at the $10 \%$ level. The sign of the coefficient of $\triangle B E T A$, however, does not conform to the expected positive relationship with bank financial distress as can be seen in the univariate regression result.

Two market indicators appear to increase the predictive power of the model based only on $\triangle N L \_D E P$ for group B banks: CAR and EXCRCUMNEG. However, only the sign of EXCRCUMNEG conforms to the expected relationship with bank financial distress.

The tests at the bottom of the table indicate that, whatever the group of countries, market information contribute to the model's overall fit as we can reject the null hypothesis that market indicators are not significant at the $5 \%$ significance level. 
Therefore our results support the conjecture that the introduction of market indicators in the prediction model can add information not yet contained in accounting data. The signs of the coefficients associated with these indicators, though, are not always the expected ones.

\subsection{Balance sheet structure effects}

We study the accuracy of market indicators for different balance sheet profiles. First, we consider the structure of assets via the importance of the ratio of net loans to total assets. Then, we study the impact of the structure of liabilities on the effectiveness of market indicators by considering the importance of the ratio of market funded liabilities to total assets. In each case, we consider the impact of the balance sheet structure (assets or liabilities) by introducing a dummy variable that takes the value of one for banks with a value of the considered ratio higher than the median value of the ratio and zero otherwise. We also run the regressions on two sub-samples constructed on the basis of the value of the dummy variable.

The model specification to capture the effects is as follows:

$$
\operatorname{Prob}\left(Y_{i}=1\right)=\Phi\left(\alpha+\delta G R P B_{i}+\sum_{j=1}^{J} \beta_{j} C_{j i}+\sum_{l=1}^{L} \gamma_{l} M_{l i}+\sum_{l=1}^{L} \gamma_{l}{ }^{\prime} D U M_{i} M_{l i}\right)
$$

where $\mathrm{DUM}_{\mathrm{i}}$ is a dummy variable which captures the considered effect.

A test to assess the hypothesis that the considered effect neutralizes the predictive power of each market indicator $\left(H_{0}: \gamma_{l}+\gamma^{\prime}{ }_{l}=0 \forall 1\right)$ is conducted.

Estimations are also conducted on two sub-samples defined on the basis of the value of the dummy variable. Due to data limitations, estimations are only run on the regional sample of banks (full sample).

Besides, because the change in the distance to default $\triangle \mathrm{DD}$ has the wrong sign in our estimations we omit this variable in our further investigations ${ }^{6}$.

\footnotetext{
${ }^{6}$ We also ran the estimation with $\triangle \mathrm{DD}$ and we found the same results. Besides, running the second stepwise procedure without $\triangle \mathrm{DD}$ does not lead to the selection of another significant market indicator.
} 


\subsubsection{Structure of bank assets}

We study the effectiveness of market indicators depending on the importance of loan activities. Indeed, banks focused on loans can be considered as more opaque and the effectiveness of market indicators may be weaker for such banks.

Insert Table 9

When we introduce the dummy variable DNLTA, we notice that the market indicator EXCRCUM is significant only for banks with a high ratio of net loans to total assets, as shown by the result of the test at the bottom of table 9 . This finding is confirmed when we run the regressions on the two sub-samples.

Thus, market information seems useful only for traditional banks that is for banks highly involved in loan activities. However, to check the robustness of this result, we also run the stepwise processes separately on the two sub-samples. Results are presented in Table 10.

\section{Insert Table 10}

Two market indicators are significant to explain downgrades of banks largely involved in loan activities: cumulative market excess returns (EXCRCUM) and the change in specific risk ( $\triangle$ RISK_SPEC). These indicators perform as expected. By running the stepwise process on the sub-sample of banks with a low ratio of net loans to total assets, two other market indicators are selected. Thus, market information seems also useful for such banks. However the signs of the coefficient associated with these market indicators are not the expected ones. Thus, it seems difficult to interpret market information for such banks.

\subsubsection{Structure of bank liabilities}

The extent to which banks rely on market funding may affect the ability of market agents to assess the riskiness of banks. Thus, we study the effectiveness of market indicators depending on the importance of the ratio of market funded liabilities to total assets.

\section{Insert Table 11}


We can see in Table 11, considering both the results obtained with the dummy variable DMARKTA or the sub-samples, that the market indicator EXCRCUM is significant only for banks with a low ratio of market funded liabilities to total assets. This result is quite surprising. Thus, to check for robustness, we run stepwise processes on the two sub-samples defined on the basis of the value of the dummy variable DMARKTA.

\section{Insert Table 12}

The results presented in Table 12 show that market information is useful for both types of banks but that the effective indicators are not the same. For banks heavily relying on market funding, the change in the standard deviation of weekly returns ( $\triangle$ RISK_TOT) and the dummy variable that takes into account the existence of negative cumulative market excess returns (EXCRCUMNEG) are significant. For banks with a low ratio of market funded liabilities, the significant market variables are the change in the beta $(\triangle B E T A)$ and the difference between the natural logarithm of weekly market price and its moving average (LOGP). Thus, the structure of liabilities does not seem to affect the effectiveness of market information; the accurate market indicators are simply different in both cases.

\section{Conclusion}

The aim of this study is to determine whether equity market information can complete accounting information to predict Asian banks' financial distress. We show that the use of equity market indicators can improve the prediction model as they bring additional information not already contained in accounting indicators. These results are in line with those of Krainer and Lopez [2004] and Curry, Elmer, and Fissel [2007] in the US case, and those of Distinguin, Rous, and Tarazi [2006] in the European case.

By dividing our sample of Asian banks into two sub-groups (i.e., banks from the tiger economies and banks from emerging markets) we show that the contribution of market information to predict banks' financial distress is significant for both groups.

The results concerning balance sheet structure effects are less clear-cut. Market information appears effective to predict downgrades of banks whatever their structure of liabilities even if the accurate indicators are not the same depending on the relative importance of market funded liabilities in balance sheets. Concerning assets structure, we find that market indicators 
are significant to predict downgrades for banks that are either weakly or highly focused on loans. However, for banks with a lower extent of loans in their balance sheet, market information seems difficult to interpret.

As a whole, in the case of East Asia, bank stock prices seem to be useful to predict bank financial distress but compared to western economies (U.S. and Western Europe) their information content appears to be less clear. 

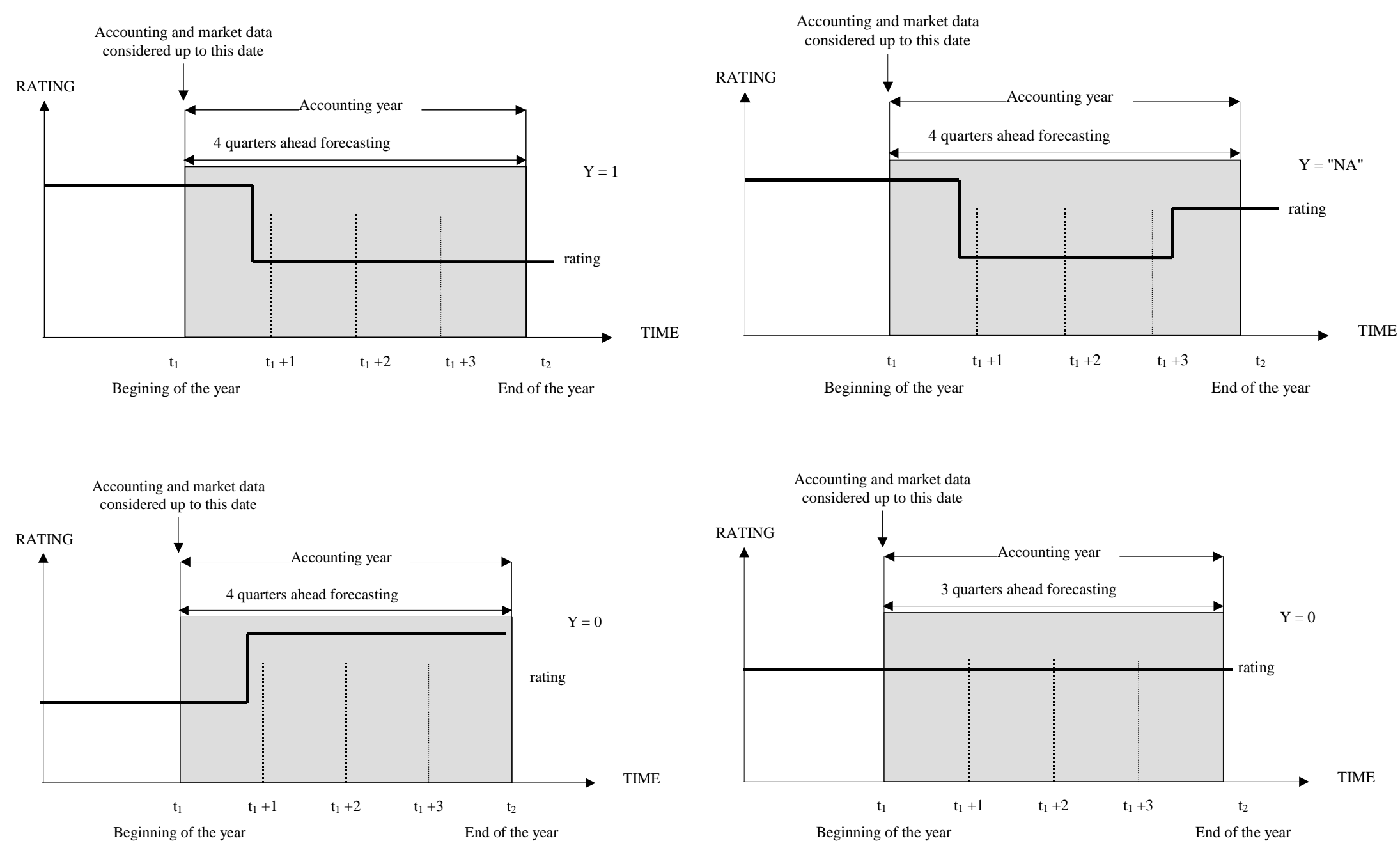

Figure 1. Definition of the Dependent Variable Y. 
Table 1. Distribution of Banks by Country and Specialization

Distribution of banks by country:

\begin{tabular}{lr} 
COUNTRY & $\begin{array}{c}\text { No. of } \\
\text { Banks }\end{array}$ \\
\hline Group A: & 8 \\
Hong Kong & 6 \\
Korea & 2 \\
Singapore & 13 \\
Taiwan & \\
Group B: & 3 \\
Malaysia & 11 \\
Indonesia & 12 \\
Thailand & 9 \\
Philippines & $\mathbf{6 4}$ \\
$\quad$ Total & \\
\cline { 2 - 2 }
\end{tabular}

Source: Bankscope Fitch IBCA

Distribution of banks by specialization:

\begin{tabular}{lrrr} 
& \multicolumn{4}{c}{ No. of Banks } \\
Specialization & A and B & \multicolumn{1}{c}{ A } & B \\
\hline Bank holding and holding & 2 & 2 & \\
company & & & \\
Commercial bank & 56 & 24 & 32 \\
Cooperative bank & 1 & 1 & \\
Investment bank & 5 & 2 & 3 \\
Total & 64 & 29 & 35 \\
\hline \hline
\end{tabular}

Source: Bankscope Fitch IBCA

Table 2. Descriptive Statistics on Summary Accounting Information

Groups $A$ and B:

\begin{tabular}{|c|c|c|c|c|}
\hline & Mean $^{2}$ & $\begin{array}{l}\text { Standard } \\
\text { Deviation }^{2}\end{array}$ & Minimum & Maximum \\
\hline Total Assets (in million USD) & 16447.57 & 23789.04 & 162.75 & 176576.30 \\
\hline Net Loans $1 /$ Total Assets (\%) & 52.14 & 17.87 & 5.57 & 94.15 \\
\hline Deposits/ Total Assets (\%) & 77.37 & 16.38 & 0.00 & 93.51 \\
\hline Subordinated Debt/ Total Assets (\%) & 1.69 & 1.66 & 0.00 & 6.79 \\
\hline Deposits (in million USD) & 13142.94 & 18174.79 & 0.00 & 126694.20 \\
\hline Subordinated Debt (in million USD) & 397.86 & 750.03 & 0.00 & 6014.69 \\
\hline Tier 1 Ratio $(\%)$ & 12.70 & 13.72 & 4.60 & 24.80 \\
\hline $\operatorname{ROA}(\%)$ & 0.78 & 1.88 & -12.13 & 12.79 \\
\hline
\end{tabular}

${ }^{1}$ Net loans are defined as gross loans less loan loss reserves.

${ }^{2}$ Each mean is calculated as $\bar{X}=\frac{1}{N T} \sum_{t=1}^{T} \sum_{j=1}^{N} X_{j t}$ where $\mathrm{N}$ is the number of banks and $\mathrm{T}$ is the number of financial reports. Standard deviations were computed on a similar basis. 
Group A:

\begin{tabular}{|c|c|c|c|c|}
\hline & Mean $^{2}$ & $\begin{array}{l}\text { Standard } \\
\text { Deviation }\end{array}$ & Minimum & Maximum \\
\hline Total Assets (in million USD) & 26462.82 & 31953.78 & 271.40 & 176576.30 \\
\hline Net Loans $1 /$ Total Assets (\%) & 59.35 & 15.40 & 5.57 & 80.42 \\
\hline Deposits/ Total Assets (\%) & 78.29 & 18.26 & 4.52 & 93.51 \\
\hline Subordinated Debt/ Total Assets (\%) & 2.10 & 1.45 & 0.00 & 5.63 \\
\hline Deposits (in million USD) & 20984.88 & 24062.07 & 54.62 & 126694.20 \\
\hline Subordinated Debt (in million USD) & 811.40 & 1122.54 & 0.00 & 6014.69 \\
\hline Tier 1 Ratio (\%) & 13.72 & 18.49 & 4.60 & 20.30 \\
\hline $\operatorname{ROA}(\%)$ & 0.48 & 1.13 & -5.53 & 4.24 \\
\hline
\end{tabular}

${ }^{1}$ Net loans are defined as gross loans less loan loss reserves.

${ }^{2}$ Each mean is calculated as $\bar{X}=\frac{1}{N T} \sum_{t=1}^{T} \sum_{j=1}^{N} X_{j t}$ where $\mathrm{N}$ is the number of banks and $\mathrm{T}$ is the number of financial reports. Standard deviations were computed on a similar basis.

Group B:

Standard

Mean $^{2} \quad$ Deviation $^{2}$ Minimum Maximum

Total Assets (in million USD)

Net Loans ${ }^{1}$ / Total Assets (\%)

Deposits/ Total Assets (\%)

Subordinated Debt/ Total Assets

(\%)

Deposits (in million USD)

Subordinated Debt (in million

USD)

Tier 1 Ratio (\%)

ROA $(\%)$
8518.84

46.43

76.64

1.49

6934.73

188.26

11.58

1.02
8151.21

17.66

14.74

1.73

$162.75 \quad 36006.70$

$8.19 \quad 94.15$

0.00

92.59

0.00

6.79

${ }^{1}$ Net loans are defined as gross loans less loan loss reserves.

${ }^{2}$ Each mean is calculated as $\bar{X}=\frac{1}{N T} \sum_{t=1}^{T} \sum_{j=1}^{N} X_{j t}$ where $\mathrm{N}$ is the number of banks and $\mathrm{T}$ is the number of financial reports. Standard deviations were computed on a similar basis.

Table 3. Downgrades Information

(Number of clean downgrades in parenthesis)

Groups A and B:

2001

2002

4.70

0.00

30802.41

289.38

0.00

1089.29

2.28

5.20

24.80

12.79

\begin{tabular}{|c|c|c|c|c|c|c|}
\hline & & 2001 & 2002 & 2003 & 2004 & 2005 \\
\hline $45(20)$ & Total downgrades & $18(6)$ & $9(7)$ & $1(1)$ & $3(1)$ & $14(5)$ \\
\hline \multirow[t]{2}{*}{$4(1)$} & Downgrades by Standard and & & & & & \\
\hline & Poor's & $3(0)$ & $1(1)$ & $0(0)$ & $0(0)$ & $0(0)$ \\
\hline $21(13)$ & Downgrades by Fitch & $5(3)$ & $8(6)$ & $1(1)$ & $0(0)$ & $7(3)$ \\
\hline $20(6)$ & Downgrades by Moody's & $10(3)$ & $0(0)$ & $0(0)$ & $3(1)$ & $7(2)$ \\
\hline
\end{tabular}


Group A:

\begin{tabular}{rlccccc} 
& $\mathbf{2 0 0 1}$ & $\mathbf{2 0 0 2}$ & $\mathbf{2 0 0 3}$ & $\mathbf{2 0 0 4}$ & $\mathbf{2 0 0 5}$ \\
\hline $21(13)$ & Total downgrades & $9(4)$ & $9(7)$ & $1(1)$ & $0(0)$ & $2(1)$ \\
$1(1)$ & $\begin{array}{l}\text { Downgrades by Standard and } \\
\text { Poor's }\end{array}$ & $0(0)$ & $1(1)$ & $0(0)$ & $0(0)$ & $0(0)$ \\
$14(11)$ & Downgrades by Fitch & $5(3)$ & $8(6)$ & $1(1)$ & $0(0)$ & $0(0)$ \\
6 (2) & Downgrades by Moody's & $4(1)$ & $0(0)$ & $0(0)$ & $0(0)$ & $2(1)$ \\
\hline \hline
\end{tabular}

Group B:

$\begin{array}{lllll}2001 & 2002 & 2003 & 2004 & 2005\end{array}$

\begin{tabular}{|c|c|c|c|c|c|c|}
\hline $24(7)$ & Total downgrades & $9(2)$ & $0(0)$ & $0(0)$ & $3(1)$ & $12(4)$ \\
\hline $3(0)$ & $\begin{array}{l}\text { Downgrades by Standard and } \\
\text { Poor's }\end{array}$ & $3(0)$ & $0(0)$ & $0(0)$ & $0(0)$ & $0(0)$ \\
\hline $7(3)$ & Downgrades by Fitch & $0(0)$ & $0(0)$ & $0(0)$ & $0(0)$ & $7(3)$ \\
\hline $14(4)$ & Downgrades by Moody's & $6(2)$ & $0(0)$ & $0(0)$ & $3(1)$ & $5(1)$ \\
\hline
\end{tabular}

Source: Bankscope Fitch IBCA and FinInfo 
Table 4. Accounting Ratios $\mathbf{R}_{\mathbf{j}}$

Category Name Definitions

\begin{tabular}{cll}
\hline \multirow{5}{*}{ Capital } & KP_NL & Equity/ Net Loans \\
& KP_DEPSTF & Equity/ Customer and ST Fundings \\
& KP_LIAB & Equity/ Liabilities \\
& TCR & Total Capital Ratio \\
\hline \multirow{5}{*}{ Asset } & LLP_TA & Loan Loss Provision/ Total Assets \\
& LLP_GL & Loan Loss Provision/ Gross Loans \\
& RWA_TA & Risk-weighted Assets and Off-balance Sheet Risks \\
& & (inferred from the Cooke ratio)/ Total Assets \\
& LLR_TA & Loan Loss Reserves/ Total Assets \\
\hline \multirow{5}{*}{ Earnings } & LLP_NETIR & Loan Loss Reserves/ Gross Loans \\
& NIR_NINC & Loan Loss Provision/ Net Interest Revenue \\
& ROAA & Net Interest Revenue/ Net Income \\
& ROAE & Net Interest Revenue/ Total Earning Assets \\
INTERBK & Return on Assets = Net Income/ Total Assets \\
& LIQASS_TOTDB & Return on Equity = Net Income/ Equity \\
\hline \hline & NL_DEP & Interbank Assets/ Interbank Liabilities \\
NL_TEA & Net Loans/ Customer and ST Fundings \\
& TRAD_OPINC & Net Loans/ Total Earning Assets \\
& (Trading Income-Trading Expense)/ Operating Income \\
\hline
\end{tabular}

\footnotetext{
${ }^{7}$ This ratio is obtained by dividing the denominator of the Cooke ratio by total assets. Note that if we were to omit off-balance sheet risks the value of this ratio would range from 0 (lowest possible level of asset risk) to 1 (highest possible level of asset risk). Because the Cooke ratio also accounts for off-balance sheet risks, the value of this indicator can be larger than 1, indicating an even higher exposure to risk.
} 
Table 5. Market Indicators

\begin{tabular}{|c|c|c|}
\hline Indicators & Definition & $\begin{array}{l}\text { Expected sign of the } \\
\text { coefficient }\end{array}$ \\
\hline LOGP & $\begin{array}{l}\text { Difference between the natural logarithm of weekly market price and its moving average calculated on one } \\
\text { year. }\end{array}$ & Negative \\
\hline RCUM & $\begin{array}{l}\text { Cumulative return: } R C U M_{b t}=\left(\left(\prod_{k=1}^{13}\left(1+r_{b, t-k+1}\right)\right)-1\right) \text { with } \mathrm{r}_{\mathrm{b}, \mathrm{t}+1}=\left(P_{b, t+1}-P_{b, t}\right) / P_{b, t} \text { where } \mathrm{r}_{\mathrm{bt}} \text { is the weekly } \\
\text { return of the stock } \mathrm{b} \text {; we calculate this cumulative return on the fourth quarter of the accounting period } \\
\text { (financial year) preceding the event, } \mathrm{P}_{\mathrm{bt}} \text { is the weekly stock price of bank } \mathrm{b} \text {. }\end{array}$ & Negative \\
\hline RCUMNEG & $\begin{array}{l}\text { Dummy variable equal to one if the cumulative return is negative in the two last quarters of the accounting } \\
\text { period (financial year) preceding the event, and zero otherwise. }\end{array}$ & Positive \\
\hline EXCRCUM & $\begin{array}{l}\text { Cumulative market excess return: } \operatorname{EXCRCUM}_{b, t}=\left(\left(\prod_{k=1}^{13}\left(1+r_{b, t-k+1}\right)\right)-1\right)-\left(\left(\prod_{k=1}^{13}\left(1+r_{m, t-k+1}\right)\right)-1\right) \\
\text { We obtain } \mathrm{r}_{\mathrm{m}} \text {, the weekly market return, which we calculate from the country-specific market index, from } \\
\text { Datastream International for the fourth quarter of the financial exercise preceding the event. }\end{array}$ & Negative \\
\hline EXCRCUMNEG & $\begin{array}{l}\text { Dummy variable equal to one if the cumulative market excess return is negative in the two last quarters of the } \\
\text { accounting period (financial year) preceding the event, and zero otherwise. }\end{array}$ & Positive \\
\hline CAR & $\begin{array}{l}\text { Cumulative abnormal returns on the fourth quarter of the accounting period (financial year) preceding the } \\
\text { event: } \mathrm{RAC}_{\mathrm{bt}}=\sum_{k=1}^{13} R A_{b, t-k+1} \text { with } \mathrm{RA}_{\mathrm{bt}}=\mathrm{R}_{\mathrm{bt}}\left(\hat{\alpha}+\hat{\beta} R_{m t}\right) . \text { We estimate the market model on the third quarter of } \\
\text { the accounting period (financial year) preceding the event }\end{array}$ & Negative \\
\hline$\Delta$ RISK_TOT & $\begin{array}{l}\text { Change in the standard deviation of weekly returns between the third and fourth quarter of the accounting } \\
\text { period (financial year) preceding the event. }\end{array}$ & Positive \\
\hline$\triangle \mathrm{BETA}$ & $\begin{array}{l}\text { Change in the market model beta }\left(\hat{R}_{b t}=\hat{\alpha}+\hat{\beta} R_{m t}\right) \text { between the third and fourth quarter of the accounting } \\
\text { period (financial year) preceding the event }\end{array}$ & Positive \\
\hline$\triangle$ RISK_SPEC & $\begin{array}{l}\text { Change in specific risk: standard deviation of the market model residual between the third and fourth quarter } \\
\text { of the accounting period (financial year) preceding the event. }\end{array}$ & Positive \\
\hline$\Delta \mathrm{Z}$ & $\begin{array}{l}\text { Change in the } \mathrm{Z} \text {-score between the third and fourth quarter of the accounting period (financial year) preceding } \\
\text { the event with: } \mathrm{Z}=\left(1+\bar{r}_{b}\right) / \sigma_{r} \text { where } \bar{r}_{b} \text { is the mean return of stock b on the preceding quarter and } \sigma_{r} \text { the } \\
\text { standard deviation of the return. }\end{array}$ & Negative \\
\hline$\Delta \mathrm{DD}$ & $\begin{array}{l}\text { Annual change in the distance to default estimated at the end of the accounting period (financial year) } \\
\text { preceding the event. We infer the distance to default from the market value of a risky debt (Merton (1977)) } \\
\text { based on the Black and Scholes (1973) option pricing formula (see Appendix). }\end{array}$ & Negative \\
\hline
\end{tabular}


Table 6. Financial Deterioration and Early Indicators: Univariate Regressions

Model Specification: Prob $\left\{Y_{i}=1\right\}=\Phi\left(\alpha+\beta X_{i}\right)$, for Groups A and B

Prob $\left\{Y_{i}=1\right\}=\Phi\left(\alpha+\delta G R P B_{i}+\beta X_{i}\right)$, for Regional

\begin{tabular}{|c|c|c|c|c|c|}
\hline & & & Regional & Grp A & Grp B \\
\hline \multirow{7}{*}{ 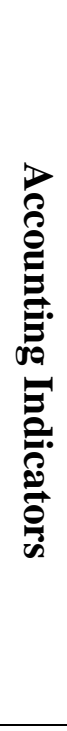 } & Earnings & $\Delta$ NIR_EA & $\begin{array}{l}-0.5783 * * \\
2.1516\end{array}$ & $\begin{array}{l}-1.1414 * \\
-1.8172\end{array}$ & \\
\hline & Earnings & $\triangle \mathrm{ROAA}$ & $\begin{array}{l}-0.1183 * * \\
-2.0399 \\
\end{array}$ & & $\begin{array}{l}-0.0889 * * \\
-2.1900 \\
\end{array}$ \\
\hline & Liquidity & $\triangle \mathrm{NL} \_D E P$ & $\begin{array}{l}-0.0686 * * * \\
-3.0984\end{array}$ & $\begin{array}{l}-0.1105 * * * \\
-2.5313\end{array}$ & $\begin{array}{l}-0.0512 \text { ** } \\
-2.4117\end{array}$ \\
\hline & Liquidity & $\Delta \mathrm{NL} \_\mathrm{TEA}$ & $\begin{array}{l}-0.0293 * * \\
-1.9355\end{array}$ & $\begin{array}{l}-0.0794 * \\
-1.6703 \\
\end{array}$ & \\
\hline & Liquidity & $\triangle$ LIQASS_TOTDB & & $\begin{array}{l}0.0466 * * \\
2.0615\end{array}$ & \\
\hline & Capital & $\triangle \mathrm{KP} \_D E P S T F$ & & & $\begin{array}{l}-0.0628 * \\
-1.8405\end{array}$ \\
\hline & Capital & $\Delta \mathrm{KP} \_L I A B$ & & & $\begin{array}{l}-0.0902 * * \\
-2.0113\end{array}$ \\
\hline \multirow{8}{*}{ 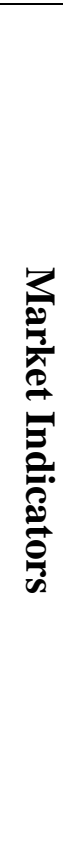 } & & EXCRCUM & \begin{tabular}{|c|}
$-37.1165 * *$ \\
2.3148 \\
\end{tabular} & $\begin{array}{l}-75.4909 * * * \\
-2.6605 \\
\end{array}$ & \\
\hline & & $\Delta \mathrm{DD}$ & $\begin{array}{l}0.5853 * * \\
1.9898 \\
\end{array}$ & & $\begin{array}{l}0.7156 * \\
1.8449 \\
\end{array}$ \\
\hline & & CAR & & $\begin{array}{l}-2.2359 * * \\
-2.0397\end{array}$ & \\
\hline & & LOGP & & $\begin{array}{l}-4.5224 * * * \\
-2.6669 \\
\end{array}$ & $\begin{array}{l}1.8601 \text { ** } \\
2.3191\end{array}$ \\
\hline & & RCUM & & $\begin{array}{c}-43.6537 * \\
-1.7512 \\
\end{array}$ & \\
\hline & & RCUMNEG & & $\begin{array}{l}1.3218 * * \\
2.1266 \\
\end{array}$ & \\
\hline & & $\triangle \mathrm{BETA}$ & & $\begin{array}{l}-2.9976 * \\
-1.7018 \\
\end{array}$ & \\
\hline & & $\Delta$ RISK_TOT & & & $\begin{array}{c}64.0651 * \\
1.8185 \\
\end{array}$ \\
\hline
\end{tabular}

This table shows simple logit estimation results where the dependent variable is separately regressed on each explanatory variable and a constant. For regional estimations, a dummy variable (GRPB), which is equal to 1, if the bank belongs to group B; and 0, otherwise, is added. This model explains downgrades (whatever their extent) that occur in the next calendar year. Standard errors are adjusted using the Huber-White method. ***, ** and * pertain to 1,5 and $10 \%$ level of significance, respectively. Z-Stats are in italics. 
Table 7. Financial Deterioration and Early Indicators: Stepwise Results - Accounting Indicators

Model Specification: Prob $\left\{Y_{i}=1\right\}=\Phi\left(\alpha+\sum_{j=1}^{J} \beta_{j} C_{j i}\right)$, for Groups A and B

$$
\text { Prob }\left\{Y_{i}=1\right\}=\Phi\left(\alpha+\delta G R P B_{i}+\sum_{j=1}^{J} \beta_{j} C_{j i}\right) \text {, for Regional }
$$

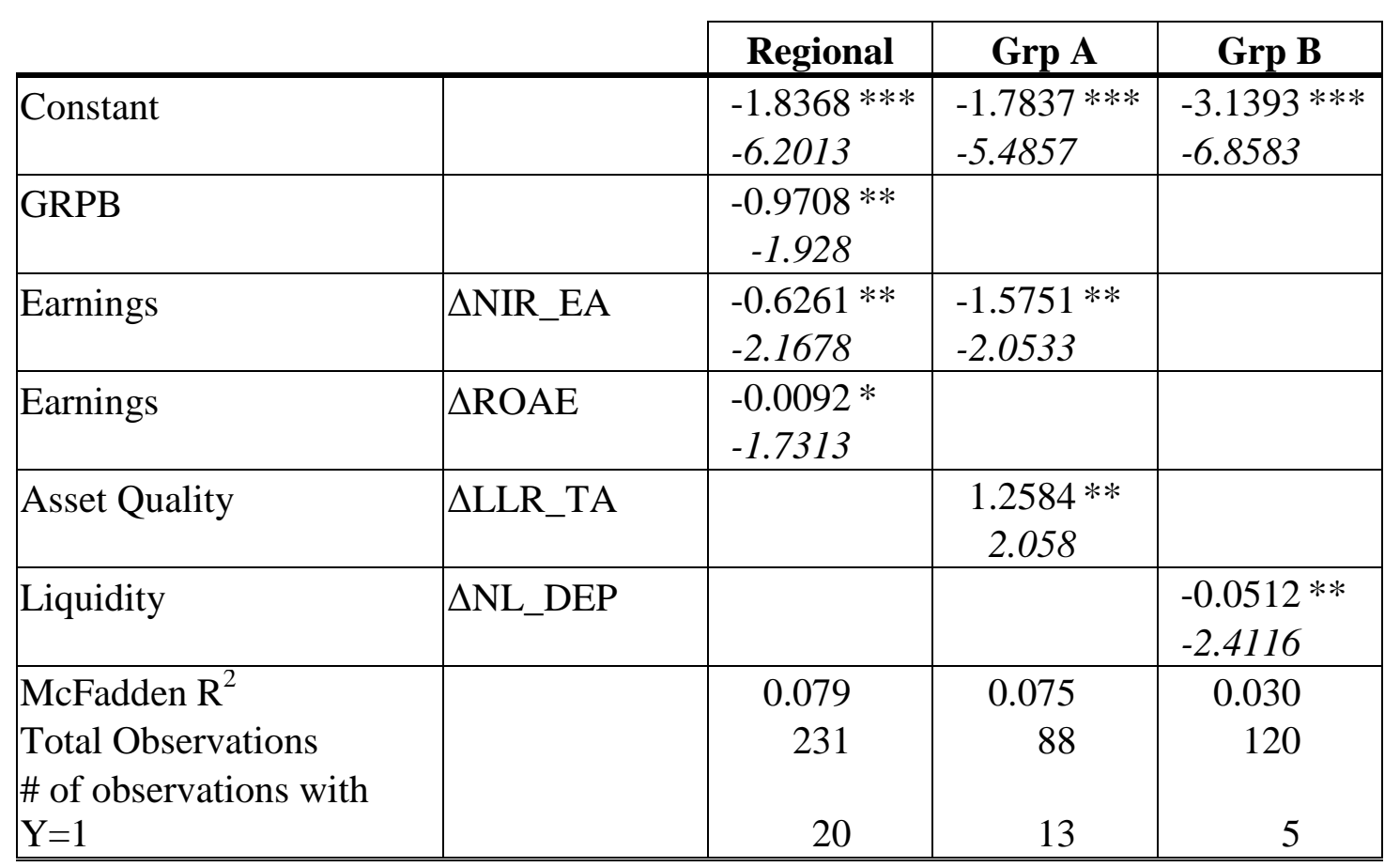

This table shows logit estimation results where the dependent variable is regressed on a constant and the accounting indicators selected by a stepwise process. For regional estimations, a dummy variable (GRPB), which is equal to 1 , if the bank belongs to group B; and 0 , otherwise, is added. This model explains downgrades (whatever their extent) that occur in the next calendar year. Standard errors are adjusted using the Huber-White method. ***, ** and * pertain to 1, 5 and $10 \%$ level of significance, respectively. Z-Stats are in italics. The number of observations in the regional model is not equal to the sum of the number of observations of Group A and Group B models because all data are not available for each bank, each year and each indicator. 
Table 8. Financial Deterioration and Early Indicators: Stepwise Results - With Market Indicators

Model Specification: Prob $\left\{Y_{i}=1\right\}=\Phi\left(\alpha+\sum_{j=1}^{J} \beta_{j} C_{j i}+\sum_{l=1}^{L} \gamma_{l} M_{l i}\right)$, for Groups A and B Prob $\left\{Y_{i}=1\right\}=\Phi\left(\alpha+\delta G R P B_{i}+\sum_{j=1}^{J} \beta_{j} C_{j i}+\sum_{l=1}^{L} \gamma_{l} M_{l i}\right)$, for Regional

\begin{tabular}{|c|c|c|c|c|}
\hline & \multirow{3}{*}{\begin{tabular}{|l|} 
Regional \\
$-2.0372 * * *$ \\
-5.3066
\end{tabular}} & \multirow{3}{*}{$\begin{array}{l}\frac{\text { Grp A }}{1.7677 * * *} \\
-4.8999\end{array}$} & \multirow{3}{*}{\begin{tabular}{|l|}
\multicolumn{1}{|c|}{ Grp B } \\
$-4.4172 * * *$ \\
-4.1608
\end{tabular}} \\
\hline & & & & \\
\hline Constant & & & & \\
\hline GRPB & & $\begin{array}{l}-1.1066 * * \\
-2.1054\end{array}$ & & \\
\hline Earnings & $\Delta$ NIR_EA & $\begin{array}{l}-0.6024 * * \\
-1.9934\end{array}$ & $\begin{array}{l}-2.8627 \\
-1.4758\end{array}$ & \\
\hline Earnings & $\triangle \mathrm{ROAE}$ & $\begin{array}{l}-0.0215 * * \\
-2.1702\end{array}$ & & \\
\hline Asset Quality & $\Delta$ LLR_TA & & $\begin{array}{l}1.8636^{*} \\
1.7217\end{array}$ & \\
\hline Liquidity & $\Delta \mathrm{NL} \_\mathrm{DEP}$ & & & $\begin{array}{l}-0.1062 * * * \\
-2.8877\end{array}$ \\
\hline \multirow{6}{*}{ Market Indicators } & EXCRCUM & $\begin{array}{l}-37.1166 * * \\
-2.1353 \\
\end{array}$ & & \\
\hline & $\Delta \mathrm{DD}$ & $\begin{array}{l}0.7621 * * * \\
2.5579\end{array}$ & & \\
\hline & LOGP & & $\begin{array}{l}-4.6914 * * \\
-2.3038\end{array}$ & \\
\hline & $\triangle \mathrm{BETA}$ & & $\begin{array}{l}-7.9047 * * \\
-1.9322\end{array}$ & \\
\hline & CAR & & & $\begin{array}{l}7.3578 \text { *** } \\
2.9005\end{array}$ \\
\hline & EXCRCUMNEG & & & $\begin{array}{l}2.0263 * \\
1.6743\end{array}$ \\
\hline $\begin{array}{l}\text { Risk level to reject } \gamma_{1}=0 \\
\forall 1\end{array}$ & & $1.27 \% * *$ & $1.95 \% * *$ & $1.21 \% * *$ \\
\hline $\begin{array}{l}\text { McFadden } \mathrm{R}^{2} \\
\text { Total Observations } \\
\# \text { of observations with } \\
\mathrm{Y}=1\end{array}$ & & $\begin{array}{r}0.163 \\
187 \\
\\
20 \\
\end{array}$ & $\begin{array}{r}0.28 \\
85 \\
13\end{array}$ & $\begin{array}{r}0.185 \\
107 \\
\\
5 \\
\end{array}$ \\
\hline
\end{tabular}

This table shows logit estimation results where the dependent variable is regressed on a constant, the accounting indicators previously selected and the market indicators selected by the stepwise process. For regional estimations, a dummy variable (GRPB), which is equal to 1 , if the bank belongs to group B; and 0 , otherwise, is added. This model explains downgrades (whatever their extent) that occur in the next calendar year. Standard errors are adjusted using the Huber-White method. $* * *, * *$ and $*$ pertain to 1,5 and $10 \%$ level of significance, respectively. Z-Stats are in italics. The number of observations in the regional model is not equal to the sum of the number of observations of Group A and Group B models because all data are not available for each bank, each year and each indicator. 
Table 9 Market Indicators and the structure of assets

Model Specification:

Prob $\left\{Y_{i}=1\right\}=\Phi\left(\alpha+\delta G R P B_{i}+\sum_{j=1}^{J} \beta_{j} C_{j i}+\sum_{l=1}^{L} \gamma_{l} M_{l i}+\sum_{l=1}^{L} \gamma_{l}^{\prime}\left(D N L T A_{i} \times M_{l i}\right)\right)$, for the whole sample

Prob $\left\{Y_{i}=1\right\}=\Phi\left(\alpha+\delta G R P B_{i}+\sum_{j=1}^{J} \beta_{j} C_{j i}+\sum_{l=1}^{L} \gamma_{l} M_{l i}\right)$, for sub-samples

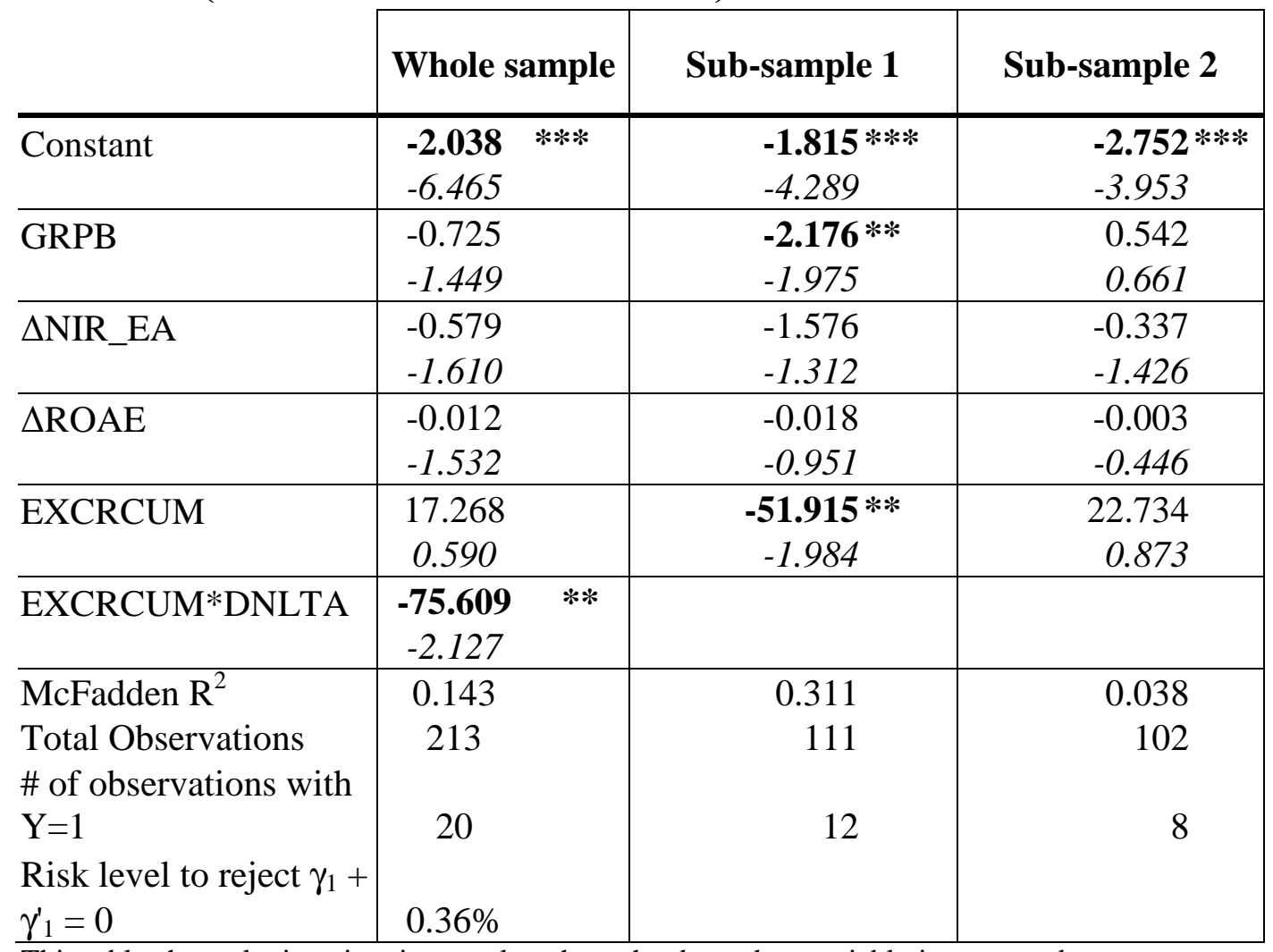

This table shows logit estimation results where the dependent variable is regressed on a constant, the accounting indicators and the market indicators selected by the stepwise processes and a dummy variable (GRPB) equal to 1 , if the bank belongs to group B; 0 , otherwise. This model explains downgrades (whatever their extent) that occur in the next calendar year. Assets structure effect is taken into account in the first column with the dummy variable DNLTA associated with market indicators. DNLTA is equal to 1 , if the ratio net loans/ total assets is higher than its median value $(54.72 \%)$. Standard errors are adjusted using the Huber-White method. ***, ** and * pertain to 1,5 and $10 \%$ level of significance, respectively. Z-Stats are in italics. Sub-sample 1 includes banks for which DNLTA=1, while sub-sample 2 includes banks for which DNLTA=0. 
Table 10 Market Indicators and the structure of assets: new stepwise ${ }^{8}$

Model Specification:

Prob $\left\{Y_{i}=1\right\}=\Phi\left(\alpha+\delta G R P B_{i}+\sum_{j=1}^{J} \beta_{j} C_{j i}+\sum_{l=1}^{L} \gamma_{l} M_{l i}\right)$, for sub-samples

\begin{tabular}{|c|c|c|}
\hline & Sub-sample 1 & Sub-sample 2 \\
\hline Constant & $\begin{array}{l}-1.691 * * * \\
-3.471\end{array}$ & $\begin{array}{l}\mathbf{- 2 . 7 5 8} * * * \\
-3.722\end{array}$ \\
\hline GRPB & $\begin{array}{l}-5.210 * * * \\
-3.113\end{array}$ & $\begin{array}{l}0.596 \\
0.663\end{array}$ \\
\hline$\Delta$ NIR_EA & $\begin{array}{l}-1.904 \\
-1.622\end{array}$ & \\
\hline$\triangle \mathrm{KP} \_D E P S T F$ & $\begin{array}{l}-\mathbf{- 0 . 3 4 3} * \\
-1.792\end{array}$ & \\
\hline ALLR_GL & $\begin{array}{l}0.245 \\
1.040\end{array}$ & \\
\hline$\overline{\Delta K P \_L I A B}$ & & $\begin{array}{l}-0.032 \\
-1.135\end{array}$ \\
\hline EXCRCUM & $\begin{array}{l}\mathbf{- 9 7 . 3 9 2} * * * * \\
-2.597\end{array}$ & \\
\hline$\triangle \mathrm{RISKSPEC}$ & $\begin{array}{c}172.47 * \\
1.838\end{array}$ & \\
\hline RCUMNEG & & $\begin{array}{l}\mathbf{- 1 . 8 1 0} * * \\
-2.519\end{array}$ \\
\hline$\overline{\Delta Z}$ & & $\begin{array}{l}\mathbf{0 . 1 3 6 *} \\
1.785\end{array}$ \\
\hline $\begin{array}{l}\text { McFadden } \mathrm{R}^{2} \\
\text { Total Observations } \\
\# \text { of observations } \\
\text { with } \mathrm{Y}=1 \\
\chi^{2} \text { stats for } \gamma_{1}=0 \\
\forall 1\end{array}$ & $\begin{array}{r}0.468 \\
110 \\
12 \\
6.91 * * \\
\end{array}$ & $\begin{array}{r}0.112 \\
103 \\
8\end{array}$ \\
\hline
\end{tabular}

This table shows logit estimation results where the dependent variable is regressed on a constant, the accounting indicators selected by a first stepwise process and the market indicators selected by a second stepwise process and a dummy variable (GRPB) equal to 1, if the bank belongs to group B; 0, otherwise. This model explains downgrades (whatever their extent) that occur in the next calendar year. Standard errors are adjusted using the Huber-White method. ***, ** and * pertain to 1,5 and $10 \%$ level of significance, respectively. Z-Stats are in italics. Sub-sample 1 includes banks for which DNLTA=1, while sub-sample 2 includes banks for which DNLTA=0.

\footnotetext{
${ }^{8}$ We run two stepwise procedures: one with the accounting indicators and the other one adding market indicators. In these stepwise procedures, we make sure that at least $75 \%$ of the observations with $Y=1$ are considered in the regressions. Here, we only report the results obtained at the end of the second procedure.
} 


\section{Table 11 Market Indicators and the structure of liabilities}

Model Specification:

Prob $\left\{Y_{i}=1\right\}=\Phi\left(\alpha+\delta G R P B_{i}+\sum_{j=1}^{J} \beta_{j} C_{j i}+\sum_{l=1}^{L} \gamma_{l} M_{l i}+\sum_{l=1}^{L} \gamma_{l}^{\prime}\left(D M A R K T A_{i} \times M_{l i}\right)\right)$, for the whole sample

$\operatorname{Prob}\left\{Y_{i}=1\right\}=\Phi\left(\alpha+\delta G R P B_{i}+\sum_{j=1}^{J} \beta_{j} C_{j i}+\sum_{l=1}^{L} \gamma_{l} M_{l i}\right)$, for sub-samples

\begin{tabular}{|c|c|c|c|}
\hline & Whole sample & Sub-sample 1 & Sub-sample 2 \\
\hline$\overline{\text { Constant }}$ & $\begin{array}{l}-\mathbf{- 1 . 8 9 1} * * * \\
-6.219\end{array}$ & $\begin{array}{l}-3.247 * * * \\
-4.122 \\
\end{array}$ & $\begin{array}{l}-\mathbf{1 . 3 8 8} * * * \\
-3.672\end{array}$ \\
\hline$\overline{\mathrm{GRPB}}$ & $\begin{array}{l}-0.938 * \\
-1.757\end{array}$ & $\begin{array}{l}1.066 \\
1.092 \\
\end{array}$ & $\begin{array}{l}-2.759 * * \\
-2.291\end{array}$ \\
\hline$\overline{\Delta N I R \_E A}$ & $\begin{array}{l}\mathbf{- 0 . 5 8 7} * \\
-1.753 \\
\end{array}$ & $\begin{array}{l}-0.562 \\
-1.465 \\
\end{array}$ & $\begin{array}{l}-0.546 \\
-0.996 \\
\end{array}$ \\
\hline$\triangle \mathrm{ROAE}$ & $\begin{array}{l}-0.012 \\
-1.547 \\
\end{array}$ & $\begin{array}{l}\mathbf{- 0 . 0 4 5} * * \\
-2.028\end{array}$ & $\begin{array}{l}-0.009 \\
-0.502 \\
\end{array}$ \\
\hline EXCRCUM & $\begin{array}{c}\mathbf{- 3 7 . 0 0 5} * \\
-1.869 \\
\end{array}$ & $\begin{array}{l}-7.830 \\
-0.278 \\
\end{array}$ & $\begin{array}{r}-39.211^{*} \\
-1.695 \\
\end{array}$ \\
\hline EXCRCUM*DMARKTA & $\begin{array}{r}14.961 \\
0.478 \\
\end{array}$ & & \\
\hline $\begin{array}{l}\text { McFadden } \mathrm{R}^{2} \\
\text { Total Observations } \\
\# \text { of observations with } \\
\mathrm{Y}=1 \\
\text { Risk level to reject } \gamma_{1}+ \\
\underline{\gamma}_{1}^{\prime}=0\end{array}$ & $\begin{array}{r}0.111 \\
213 \\
20 \\
37.44 \% \\
\end{array}$ & $\begin{array}{r}0.083 \\
109 \\
8\end{array}$ & $\begin{array}{r}0.257 \\
104 \\
12\end{array}$ \\
\hline
\end{tabular}

This table shows logit estimation results where the dependent variable is regressed on a constant, the accounting indicators and the market indicators selected by the stepwise processes and a dummy variable (GRPB) equal to 1 , if the bank belongs to group B; 0 , otherwise. This model explains downgrades (whatever their extent) that occur in the next calendar year. Assets structure effect is taken into account in the first column with the dummy variable DNLTA associated with market indicators. DMARKTA is equal to 1, if the ratio Market fundings/ total assets is higher than its median value (9.88\%). Standard errors are adjusted using the Huber-White method. ***, $* *$ and * pertain to 1,5 and $10 \%$ level of significance, respectively. Z-Stats are in italics. Subsample 1 includes banks for which DMARKTA=1, while sub-sample 2 includes banks for which DMARKTA $=0$. 
Table 12 Market Indicators and the structure of liabilities: new stepwise ${ }^{9}$

Model Specification:

Prob $\left\{Y_{i}=1\right\}=\Phi\left(\alpha+\delta G R P B_{i}+\sum_{j=1}^{J} \beta_{j} C_{j i}+\sum_{l=1}^{L} \gamma_{l} M_{l i}\right)$, for sub-samples

\begin{tabular}{|c|c|c|}
\hline & Sub-sample 1 & Sub-sample 2 \\
\hline$\overline{\text { Constant }}$ & $\begin{array}{l}-\mathbf{3 . 9 6 6} * * * \\
-5.650\end{array}$ & $\begin{array}{l}-1.324 * * * \\
-3.726\end{array}$ \\
\hline$\overline{\text { GRPB }}$ & $\begin{array}{l}1.007 \\
1.153\end{array}$ & $\begin{array}{l}\mathbf{- 3 . 0 2 5} * * \\
-2.296\end{array}$ \\
\hline DNIR_EA & & $\begin{array}{l}-1.371 * \\
-1.877\end{array}$ \\
\hline$\overline{\Delta K P \_L I A B}$ & $\begin{array}{r}-\mathbf{0 . 0 9 3} * * \\
-2.317\end{array}$ & \\
\hline$\triangle \mathrm{ROAE}$ & $\begin{array}{l}-0.024 \\
-1.371\end{array}$ & \\
\hline$\triangle \mathrm{BETA}$ & & $\begin{array}{l}\mathbf{- 5 . 7 7 4} * * \\
-2.226\end{array}$ \\
\hline LOGP & & $\begin{array}{l}-\mathbf{- 3 . 0 8 0} * \\
-1.701\end{array}$ \\
\hline$\overline{\Delta \text { RISKTOT }}$ & $\begin{array}{l}\mathbf{9 7 . 8 0 4} * * * \\
2.653\end{array}$ & \\
\hline EXCRCUMNEG & $\begin{array}{l}1.648 * \\
1.911\end{array}$ & \\
\hline $\begin{array}{l}\text { McFadden } \mathrm{R}^{2} \\
\text { Total Observations } \\
\# \text { of observations } \\
\text { with } \mathrm{Y}=1 \\
\chi^{2} \text { stats for } \gamma_{1}=0 \\
\forall 1\end{array}$ & $\begin{array}{r}0.175 \\
110\end{array}$ & $\begin{array}{r}0.314 \\
102 \\
12 \\
9.64 * * \\
\end{array}$ \\
\hline
\end{tabular}

This table shows logit estimation results where the dependent variable is regressed on a constant, the accounting indicators selected by a first stepwise process and the market indicators selected by a second stepwise process and a dummy variable (GRPB) equal to 1, if the bank belongs to group B; 0, otherwise. This model explains downgrades (whatever their extent) that occur in the next calendar year. Standard errors are adjusted using the Huber-White method. ***, ** and * pertain to 1,5 and $10 \%$ level of significance, respectively. Z-Stats are in italics. Sub-sample 1 includes banks for which DMARKTA=1, while sub-sample 2 includes banks for which DMARKTA=0.

\footnotetext{
${ }^{9}$ We run two stepwise procedures: one with the accounting indicators and the other one adding market indicators. In these stepwise procedures, we make sure that at least $75 \%$ of the observations with $Y=1$ are considered in the regressions. Here, we only report the results obtained at the end of the second procedure.
} 


\section{APPENDIX: DISTANCE TO DEFAULT}

The distance to default indicator DD - the number of standard deviations away from the default point (i.e., when the value of assets equals the value of liabilities) - is:

$$
D D_{t}=\frac{\log \left(\frac{V_{t}}{D_{t}}\right)+\left(r_{f}-\frac{\sigma_{t}^{2}}{2}\right) T}{\sigma_{t} \sqrt{T}}
$$

where:

$\mathrm{V}_{\mathrm{t}}=$ bank's asset value at time $\mathrm{t}$

$D_{t}=$ book value at time $t$ of the bank's debt of maturity $T$

$\mathrm{T}=$ debt maturity

$\mathrm{r}_{\mathrm{f}}=$ risk-free interest rate

$\sigma_{\mathrm{t}}=$ bank's asset value volatility

To estimate $V_{t}$ and $\sigma_{t}$, the value of equity as a call option on the underlying assets with a strike price equal to the book value of the bank's debt was considered. Hence, the market value and volatility of the bank's underlying assets can be derived from the equity's market value $(\mathrm{VE})$ and volatility $\left(\sigma_{\mathrm{E}}\right)$ by solving:

$$
\left\{\begin{aligned}
V_{t} & =\frac{V E_{t}+D_{t} e^{-r_{f} T} N(d 2)}{N(d 1)} \\
\sigma_{t} & =\frac{\frac{V E_{t}}{V_{t}} \sigma_{E, t}}{N(d 1)}
\end{aligned}\right.
$$

where:

$$
\begin{aligned}
& d 1=\frac{\log \left(\frac{V_{t}}{D_{t}}\right)+\left(r_{f}+\frac{\sigma_{t}^{2}}{2}\right) T}{\sigma_{t} \sqrt{T}} \\
& d 2=d 1-\sigma_{t} \sqrt{T}
\end{aligned}
$$


Weekly market values of the bank's equity (VE) were obtained from Datastream. The volatility of the bank's equity $\left(\sigma_{\mathrm{E}}\right)$ on the quarter preceding the end of the calendar year was calculated as the standard deviation of weekly equity returns multiplied by $\sqrt{365}$.

Here, the expiry date of the option (T) is equal to the maturity of the debt. A common assumption is to set it to one, i.e., one year. Interbank rates from Datastream were used to compute risk-free rates. Data on debt liabilities were obtained from Bankscope. The total amount of liabilities was calculated as the total amount of deposits, money-market funding, bonds, subordinated debt and hybrid capital. 


\section{References:}

BERGER A. N., DAVIES S. M., FLANNERY M. J., 2000, Comparing Market and Supervisory Assessments of Bank Performance: Who Knows What When?, Journal of Money, Credit and Banking, vol. 32, 641-667

BLACK F., SCHOLES M., 1973, The Pricing of Options and Corporate Liabilities, Journal of Political Economy, vol. 81, 637-654

CROSBIE P. J., BOHN P. R., 2003, Modeling Default Risk, San Francisco: KMV Corporation

CURRY T. J., ELMER P. J., FISSEL G. S., 2007, Equity market data, bank failures and market efficiency, Journal of Economics and Business, vol. 59, 536-559

CURRY T. J., FISSEL G. S., HANWECK G. A., 2008, Equity Market Information, Bank Holding Company Risk, and Market Discipline, Journal of Banking and Finance, vol. 32, 807-819

DEMIRGUC-KUNT A., DEGATRIACHE E., 2000, Monitoring Banking Sector Fragility: a Multivariate Logit Approach, The World Bank Economic Review, vol. 14, n², 287-307.

DIAMOND D. W., 1984, Financial intermediation and delegated monitoring, Review of Economic Studies, vol. 51(3), 393-414

DISTINGUIN I., ROUS P., TARAZI A., 2006, Market Discipline and the Use of Stock Market Data to Predict Bank Financial Distress, Journal of Financial Services Research, vol. $30,151-176$

EVANOFF D. D., WALL L. D., 2001, Sub-debt yield spreads as bank risk measures, Journal of Financial Services Research, vol. 20 (2/3), 121-145

$1741-1771$ 
FLANNERY M. J., 1998, Using Market Information in Prudential Bank Supervision: A Review of the U.S. Empirical Evidence, Journal of Money Credit and Banking, vol. 30, n³, 273-305

FLANNERY M. J., 2001, The Faces of Market Discipline, Journal of Financial Services Research, vol. 20, 2-3, 107-119

GREENE W. H., 2003, Econometrics Analysis, Fifth Edition, Prenctice Hall, New Jersey

GROPP R., VESALA J., VULPES G., 2006, Equity and Bond Market Signals as Leading Indicators of Bank Fragility, Journal of Money, Credit and Banking, 399-428

GUNTHER J. W., LEVONIAN M. E., MOORE R. R., 2001, Can the Stock Market tell Bank Supervisors Anything They Don't Already Know?, Economic and Financial Review, Federal Reserve Bank of Dallas

KOLARI J., GLENNON D., SHIN H., CAPUTO M., 2002, Predicting large US Commercial bank failures, Journal of Economics and Business, vol. 54, 361-387

KRAINER J., LOPEZ J. A., 2004, Incorporating Equity Market Information into Supervisory Monitoring Models, Journal of Money, Credit and Banking, vol. 36, 1043-1067

MERTON R. C., 1977, On the Pricing of Contingent Claims and the Modigliani-Miller Theorem, Journal of Financial Economics, vol. 5, 241-249 